\title{
MIMBAR HADIS DAN KULTUM UNTUK MEMBANGUN KESADARAN RELIGIUS MASYARAKAT DESA BONTO LOJONG KABUPATEN BANTAENG
}

\section{MIMBAR OF HADITH AND KULTUM TO BUILD RELIGIOUS AWARENESS OF BONTO LOJONG VILLAGE COMMUNITY BANTAENG REGENCY}

\author{
Ridwan \\ Sekolah Tinggi Ilmu Islam dan Bahasa Arab (STIBA) Makassar \\ Email : ridwanibnhambali@stiba.ac.id

\section{Sirajuddin} \\ Sekolah Tinggi Ilmu Islam dan Bahasa Arab (STIBA) Makassar \\ Email : sirajuddin@stiba.ac.id

\section{Imran} \\ Sekolah Tinggi Ilmu Islam dan Bahasa Arab (STIBA) Makassar \\ Email : imranahmad@kuis.edu.my
}

\begin{tabular}{|c|c|}
\hline Keywords : & ABSTRACT \\
\hline $\begin{array}{l}\text { Bantaeng Bonto Lojong Village, } \\
\text { Hadith, Kultum, KKN STIBA } \\
\text { Makassar }\end{array}$ & $\begin{array}{l}\text { Bonto Lojong village has a status as a definitive village and is } \\
\text { classified as a self-help village, including a village that is quite } \\
\text { potential, developed and open. However, religious activities are not } \\
\text { very lively, so this becomes the basis for the implementation of PKM } \\
\text { STIBA Makassar. To identify problems that occur in the community, } \\
\text { map problems, the needs of the da'wah movement, and develop } \\
\text { strategies for the preparation of KKN programs, soar analysis is } \\
\text { used with the results obtained; Strenght: muntea village, Bonto } \\
\text { Lojong village, Uluere sub-district and Sunggumanai sub-village } \\
\text { Pa'jukukang Pa'jukukang subdistrict Bantaeng 100\% Muslim, and } \\
\text { open-minded, and STUDENTS STIBA Makassar has been equipped } \\
\text { with good religious understanding, has da'wah skills; Oppurtunities: } \\
\text { support and cooperation of apparat villages and communities; } \\
\text { Aspiration: stakeholders facilitate the community to obtain its } \\
\text { spiritual needs; Result: people become more understanding of their } \\
\text { religion well. The results of this analysis Realize kultum activities } \\
\text { and hadith readings. After the existence of this program, people } \\
\text { began to be interested to listen to the reading of hadith and kultum } \\
\text { delivered by students of KKN STIBA Makassar. This will certainly } \\
\text { add insight to the Islamic congregation of the mosque. }\end{array}$ \\
\hline \multirow{2}{*}{$\begin{array}{l}\text { Kata kunci : } \\
\text { Bantaeng, Hadis, Kultum, Desa } \\
\text { Bonto Lojong, KKN STIBA } \\
\text { Makassar }\end{array}$} & ABSTRAK \\
\hline & $\begin{array}{l}\text { Desa Bonto Lojong berstatus sebagai desa definitif dan tergolong } \\
\text { pula sebagai desa swadaya, termasuk desa yang cukup potensial, } \\
\text { berkembang dan terbuka. Akan tetapi, aktivitas keagamaan tidak } \\
\text { terlalu semarak, sehingga ini menjadi dasar pelaksanaan PkM } \\
\text { STIBA Makassar. Untuk mengidentifikasi masalah yang terjadi di } \\
\text { masyarakat, memetakan masalah, kebutuhan gerakan dakwah, dan }\end{array}$ \\
\hline
\end{tabular}




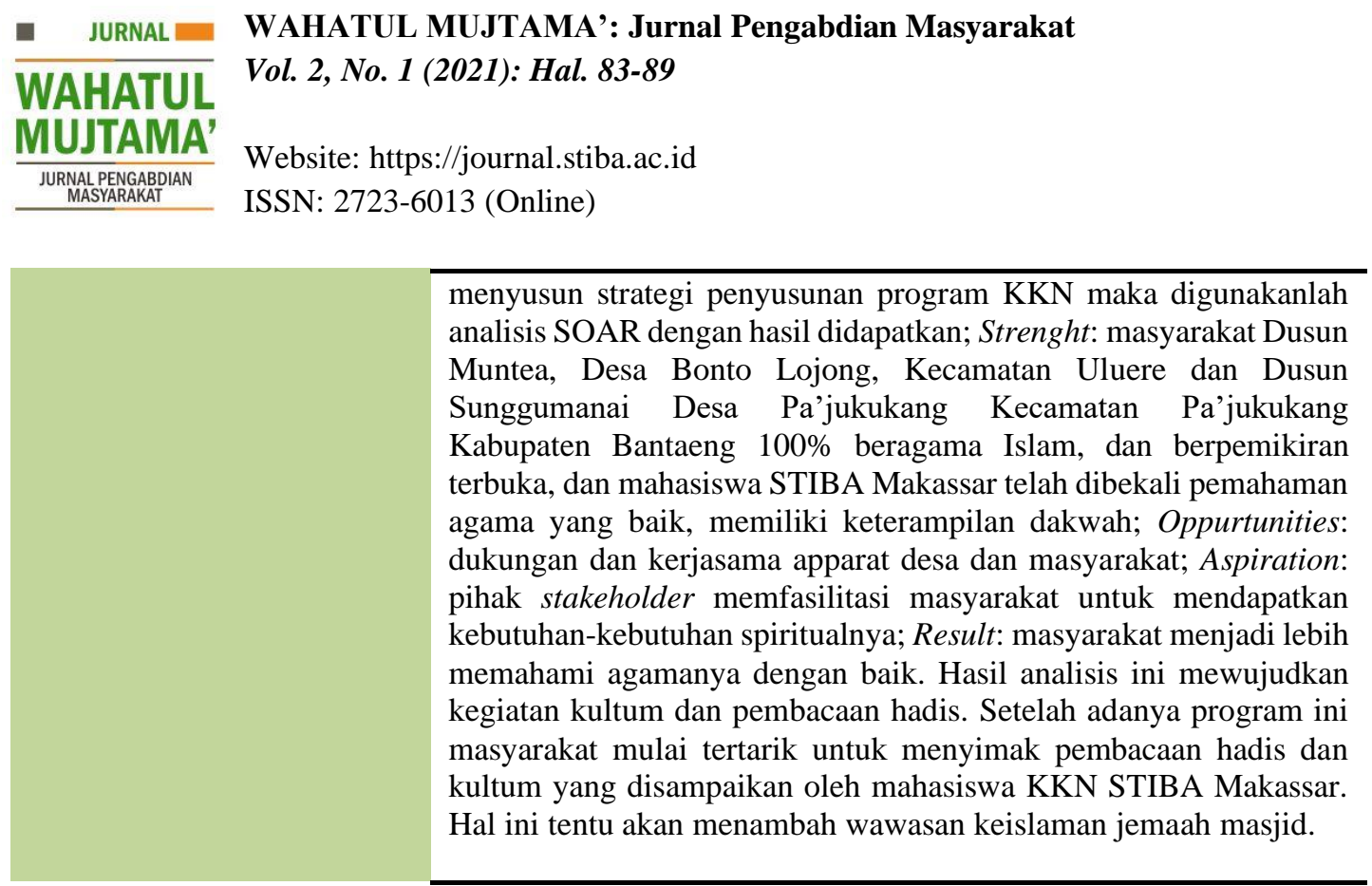

Diterima: 20 April 2021; Direvisi: 10 Mei 2021; Disetujui: 28 Mei 2021; Tersedia online: 18 Juni 2021

How to cite: Ridwan, Sirajuddin, Imran "Mimbar Hadis dan Kultum untuk Membangun Kesadaran Religius Masyarakat Desa Bonto Lojong, Kabupaten Bantaeng”, WAHATUL MUJTAMA': Jurnal Pengabdian Masyarakat Vol.2, No.1 (Juni 18, 2021): 83-89. doi: https://doi.org/10.36701/wahatul.v2i1.349

\section{PENDAHULUAN}

Desa Bonto Lojong adalah nama sebuah desa yang berada di wilayah administratif Kecamatan Uluere, Kabupaten Bantaeng, Provinsi Sulawesi Selatan, Indonesia. Kata Bonto Lojong adalah gambaran penuh dari kata dasar Bonto dalam bahasa Makassar bermakna "gunung" dan Lojong bermakna "memanjang". Jadi, Bonto Lojong adalah pegunungan yang tinggi atau gunug-gunung yang menjulang ke langit. Desa Bonto Lojong berstatus sebagai Desa definitif dan tergolong pula sebagai desa swadaya. Desa Bonto Lojong memiliki luas wilayah 41,45 $\mathrm{km}^{2}$ dan jumlah penduduk sebanyak 3.297 jiwa pada tahun 2020 dan berada pada ketinggian 1.200-1.700 Mdpl ${ }^{1}$.

Tanah di wilayah Desa Bonto Lojong sebagian besar berupa kawasan hutan dan kawasan hutan lindung dan tanah sebagai perkebunan seluas 1.679,68 Ha persegi, kemudian luas tanah yang digunakan untuk pemukiman seluas 16,30 Ha. Desa Bonto Lojong terdiri dari 7 Dusun: Dusun Bangkeng Bonto, Dusun Lannying I, Dusun Lannying II, Dusun Bissawali, Dusun Buakang Paliang, Dusun Muntea, Dusun Kayutanning. Desa Bonto Lojong memiliki cuaca dingin dengan suhu ratarata harian sebesar $15^{\circ} \mathrm{C}-19^{\circ} \mathrm{C}$, dan curah hujan yang sedang. Potensi Alam yang sangat produktif seperti lahan pertanian perkebunan dan hutan. Berbatas dengan

\footnotetext{
${ }^{1}$ Profil Desa Bonto Lojong
} 
sebelah utara: Gowa dan Sinjai. sebelah selatan: Desa Bonto Tangga. Sebelah Timur: Desa Kayu Loe, Desa Pa'bumbungan dan Kabupaten Bulukumba. Sebelah Barat: Desa Bonto Marannu dan Kabupaten Jeneponto. Desa ini mempunyai jumlah penduduk berkisar 3.279 orang.

Mayoritas mata pencaharian penduduknya pada umumnya berprofesi sebagai petani, utamanya petani sayuran dan buah, sedangkan non pertanian bergerak pada lapangan usaha perdagangan besar ataupun eceran. Desa yang dihuni oleh 100\% Muslim ini difasillitasi 19 masjid. Dengan aktivitas masyarakat yang cukup baik di beberapa organisasi desa seperti Lembaga Pemberdayaan Masyarakat (LPM), Pemberdayaan Kesejahteraan Keluarga (PKK), Karang taruna, KPA MAPIA ADVENTURE BANTAENG Serambi Baca Tau Macca (SBTM). Melihat keaktifan masyarakatnya dalam organisasi yang ada, dapat dilihat bahwa desa ini termasuk desa yang cukup potensial, berkembang dan terbuka. Akan tetapi aktivitas keagamaan tidak terlalu semarak, sehingga ini menjadi dasar pelaksanaan PkM STIBA Makassar. Dengan tujuan dari pelaksanaan pengabdian kepada masyarakat (PkM) yang hendak dilakukan oleh pihak Sekolah Tinggi Ilmu Islam dan Bahasa Arab (STIBA) Makassar sebagai berikut:

1. Menumbuhkan kesadaran sosial mahasiswa dalam berdakwah berbasis ilmu pengetahuan Islam yang telah diperoleh selama di STIBA Makassar.

2. Mengembangkan kompetensi dakwah lapangan mahasiswa STIBA Makassar.

3. Mengamalkan tri dharma perguruan tinggi bagi Dosen Pembimbing Lapangan (DPL) pada pilar pengabdian kepada masyarakat.

4. Mengembangkan eksistensi STIBA Makassar sebagai perguruan tinggi berbasis pengkaderan ulama dan organisatoris yang bermanfaat kepada masyarakat.

Untuk mengidentifikasi masalah yang terjadi di masyarakat, memetakan masalah, kebutuhan gerakan dakwah, dan menyusun strategi penyusunan program KKN maka digunakanlah analisis SOAR dengan hasil didapatkan sebagai berikut:

1. Strenght: masyarakat Dusun Muntea, Desa Bonto Lojong, Kecamatan Uluere dan Dusun Sunggumanai Desa Pa'jukukang Kecamatan Pa'jukukang Kabupaten Bantaeng 100\% beragama Islam, dan berpemikiran terbuka. Mahasiswa STIBA Makassar telah dibekali pemahaman agama yang baik, dan memiliki keterampilan berdakwah.

2. Oppurtunities: dukungan dan kerjasama aparat desa dan masyarakat.

3. Aspiration: pihak stakeholder memfasilitasi masyarakat untuk mendapatkan kebutuhan-kebutuhan spiritualnya.

4. Result: masyarakat menjadi lebih memahami agamanya dengan baik. 
Dari analisis di atas maka dibuatlah kegiatan sebagai pendekatan dakwah kepada masyarakat yaitu pembacaan hadis dan kultum. Adapun bentuk-bentuk PkM terdahulu yang relevan dengan kegiatan ini yaitu sebagai berikut:

1. PkM yang dilaksanakan oleh mahasiswa KKN STIBA Makassar angkatan III di Desa Baruga yaitu diawali dengan Seminar Program Kerja (SPK), lalu Pelatihan Penyelenggaraan Jenazah (PPJ), Silaturahmi Akbar dan Pelayanan Kesehatan (SAPK), Festival Anak Saleh (FAS) dan Rambu-Rambu Islami (RRI). Adapun hasil dari KKN ini ialah dapat dilihat dari segi pengetahuan masyarakat yang mengalami perkembangan wawasan keislaman, terutama dari sisi kemahiran mengenali huruf hijaiah, makhraj dan tajwid dalam bacaan AlQur'an. Dari segi keterampilan, terutama terlihat dari sisi kecakapan masyarakat dalam penyelenggaan jenazah. Dari segi sikap, masyarakat sudah memiliki antusiasme tinggi dalam mempelajari dan mengamalkan ilmu keislaman².

2. Salah satu masjid di wilayah Wirobrajan yang digunakan untuk KKN alternatif periode LXI yaitu Masjid Muhajirin satu komplek dengan SD Muhammadiyah Wirobrajan 3. Metode yang digunakan yaitu pendidikan masyarakat, difusi IPTEK, dan juga praktek. Segala kegiatan pada KKN ini dilakukan di masjid sehingga suasana masjid akan semakin meriah. Hasilnya, program-program sudah dilaksanakan dengan baik dan lancar serta sangat berperan dalam pengembangan pendidikan karakter anak usia sekolah yang berbasis masjid ${ }^{3}$.

3. PkM yang bertujuan untuk mengetahui dampak dari Kuliah Kerja Nyata (KKN) terhadap pengembangan kegaaman bagi remaja di Desa Cawang Lama. Pengembangan keagamaan didukung oleh beberapa faktor, salah satunya adalah Kuliah Kerja Nyata (KKN) yang dampaknya sangat berpengaruh di masyarakat. Jenis Penelitian ini merupakan penelitian lapangan (field research) dengan pendekatan deskriptif kualitatif yang objeknya adalah Desa Cawang Lama serta subjeknya adalah remaja. Dalam penelitian ini diketahui bahwa dampak KKN dalam pengembangan keagamaan bagi remaja menghasilkan dampak yang positif melalui program-program yang telah dilaksanakan oleh mahasiswa ${ }^{4}$.

\footnotetext{
${ }^{2}$ Mukran H Usman, "DESA BARUGA KABUPATEN MAROS” 1, no. 1 (2020): 75-89.

${ }^{3}$ Okka Adiyanto and K K N Alternatif, "PENUMBUHAN KARAKTER ANAK USIA SEKOLAH BERBASIS MASJID MELALUI KULIAH KERJA NYATA ( KKN ) Menurut Data Informasi Kependudukan Provinsi Daerah Istimewa Yogyakarta Berjumlah Timur: Kelurahan Pakuncen : Kelurahan Notoprajan Selatan : Kelurahan Patangpuluhan," Jurnal Pemberdayaan 2, no. 2 (2018): 333-40.

${ }^{4}$ Cheni Eka Putri Wulandari, Sugiatno Sugiatno, and Siswanto Siswanto, "Dampak Kuliah Kerja Nyata Dalam Pengembangan Keagamaan Bagi Remaja," FOKUS Jurnal Kajian Keislaman Dan Kemasyarakatan 5, no. 2 (2020): 221, https://doi.org/10.29240/jf.v5i2.1830.
} 
Website: https://journal.stiba.ac.id ISSN: 2723-6013 (Online)

Perbedaan PkM yang dilaksanakan di Dusun Muntea, Desa Bonto Lojong, Kecamatan Uluere dan Dusun Sunggumanai Desa Pa'jukukang Kecamatan Pa'jukukang Kabupaten Bantaeng dengan PkM di atas adalah kegiatan dakwah yang dilakukan secara masif dan simultan untuk mengawali semangat berislam masyarakat desa.

\section{PEMBAHASAN}

\section{Pelaksanaan Program Pembacaan Hadis dan Kultum}

Kultum dan pembacaan hadis adalah kegiatan yang bertujuan sebagai sarana siraman rohani bagi masyarakat Dusun Muntea, dengan harapan bisa memberikan pengaruh pembentukan karakter religius bagi masyarakat setempat. Secara khusus, kegiatan kultum adalah bentuk latihan berbicara di depan umum bagi mahasiswa dan berbagi motivasi serta semangat berislam kepada warga desa, selain itu, juga dapat meningkatkan kemampuan mahasiswa dalam menyampaikan nasehatnya dengan waktu yang singkat di depan orang banyak ${ }^{5}$.

Kegiatan ini dilaksanakan setiap hari setiap habis salat Subuh dan salat Magrib. Langkah-langkah yang disiapkan oleh mahasiswa KKN adalah perizinan pelaksanaan kegiatan ke pihak pengurus masjid. Hal ini menjadi faktor pendukung suksesnya kegiatan disebabkan pihak pengurus masjid memberikan kepercayaan yang besar kepada mahasiswa KKN untuk memberikan manfaat di masjid tersebut. Langkah berikutnya adalah persiapan materi kultum dan materi pembacaan hadis.

Materi didapatkan dari buku, internet dan dari catatan ceramah yang pernah didengar oleh mahasiswa KKN. Untuk memastikan materi dan metode penyampaiannya kultum dan pembacaan hadisnya tepat sasaran, maka para mahasiswa melakukan latihan (peer teaching). Hal ini penting dilakukan karena walaupun mahasiswa telah dilatih di kampus, akan tetapi audiens yang berbeda dan beragam tentu harus dengan metode yang tepat. Hal ini sekaligus sebagai bentuk tanggung jawab dan keseriusan mahasiswa untuk bisa memberikan yang terbaik. Selain itu, langkah jitu sebelum menyampaikan kultum adalah mempersiapkan materi jauh hari sebelum waktunya dan menguasai beberapa materi pamungkas, sederhana, praktis, dan mudah dicerna atau dipahami oleh masyarakat awam ${ }^{6}$.

Kegiatan yang dilaksanakan di masjid ini mendapat respon yang sangat baik dari jemaah masjid. Jumlah jemaah kurang lebih 12 orang. Kegiatan diadakan setelah salat Magrib dan salat Subuh. Dengan durasi waktu kurang lebih 7 menit

5 Tempo, Rachmat Bin Badani, and Khaerul Aqbar. "Ikhtiar Mahasiswa KKN STIBA Makassar dalam Pembentukan Akhlak Qur'ani Masyarakat Desa Balassuka Kabupaten Gowa." WAHATUL MUJTAMA': Jurnal Pengabdian Masyarakat 1.1 (2020): 90-115.

${ }^{6}$ Aqbar, Khaerul, and Putra Alam. "Stimulasi Dakwah Menuju Masyarakat Qur'ani melalui KKN STIBA Makassar di Desa Alatengae Kabupaten Maros." WAHATUL MUJTAMA': Jurnal Pengabdian Masyarakat 1.2 (2020): 209-221. 
diharapkan bisa memberikan pengaruh ke jemaah. Kultum atau kuliah 7 menit dianggap sebagai seni menyampaikan sebuah pesan kepada orang banyak dengan durasi waktu lebih singkat dari ceramah pada umumnya. Kultum bisa juga disamakan dengan ceramah singkat dan hanya membahas sedikit hal dari masalah agama atau hanya sekedar pengingat saja agar orang tidak lalai, atau motivasi untuk melakukan kebaikan-kebaikan. Kultum dan pembacaan hadis dianggap efektif karena waktunya yang singkat tetapi secara masif dianggap memberikan efek yang lebih besar dan awet.

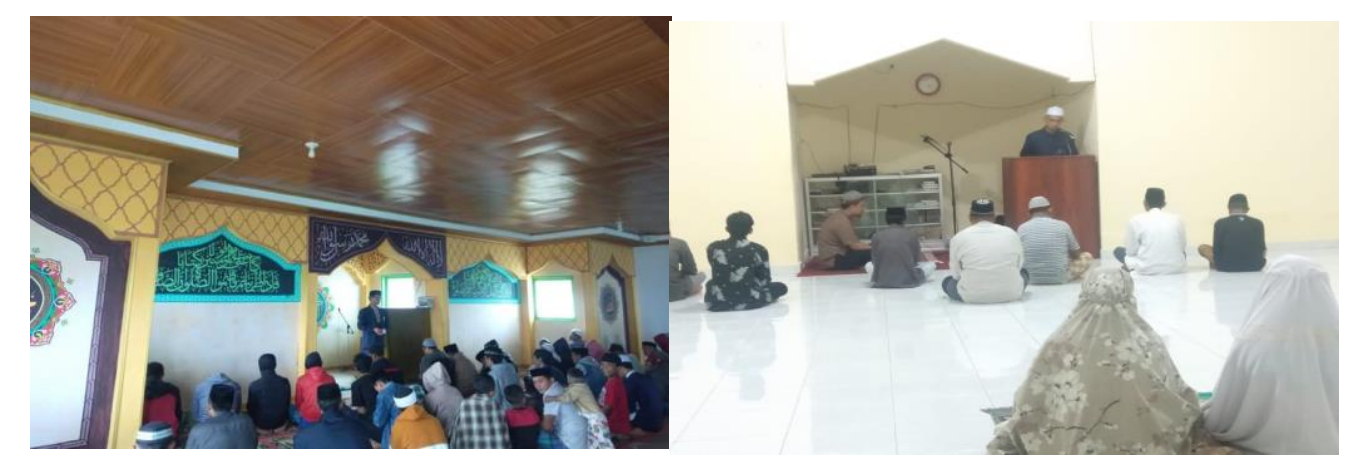

\section{Gambar 1. Penyampaian Kultum dan Pembacaan Hadis}

Untuk melihat hasil kegiatan ini dapat diamati pada perbedaan sebelum dan setelah kegiatan. Sejatinya, masyarakat di Desa Bonto Lojong setelah pelaksanaan salat berjemaah khususnya salat Subuh dan Maghrib, mereka langsung pulang ke rumah masing-masing karena tidak adanya kegiatan di masjid, sementara sebagian orang tetap di masjid sembari berbincang santai dengan jemaah yang lainnya. Terlihat bahwa orang-orang dewasa maupun usia lanjut tidak mendapat perhatian untuk diberikan sentuhan dakwah di daerah tersebut, hal ini tampak pada masjid yang tidak diberdayakan secara maksimal. Adapun setelah adanya program ini, masyarakat mulai tertarik dan menyadari akan pentingnya untuk mendapatkan ilmu dari penyampai kultum dan pembacaan hadis oleh Mahasiswa KKN STIBA Makassar, sehingga masyarakat dapat mengambil banyak manfaat dari program ini. Akhirnya, sebagai kelanjutan dari program ini maka diharapkan adanya perhatian yang lebih dari masyarakat, khususnya tokoh agama untuk melanjutkan apa yang telah dilaksanakan oleh mahasiswa KKN STIBA Makassar berupa kegiatan rutin pembacaan hadis dan penyampaian kultum. 
Website: https://journal.stiba.ac.id ISSN: 2723-6013 (Online)

\section{KESIMPULAN}

Kuliah Kerja Nyata (KKN) merupakan bentuk pengabdian yang dilakukan oleh Mahasiswa Sekolah Tinggi Ilmu Islam dan Bahasa Arab (STIBA) Makassar kepada masyarakat Dusun Muntea, Desa Bonto Lojong, Kecamatan Uluere, Kabupaten Bantaeng. Program yang dianggap bisa menjawab permasalahan atas kurang semaraknya aktifitas dakwah Dusun Muntea adalah pembacaan hadis dan kultum yang dilaksanakan setelah pelaksanaan sholat subuh dan sholat Maghrib. Pelaksanaan kedua program tersebut mendapat respon yang baik dari masyarakat ini dibuktikan dengan setelah pelaksanaan sholat kurang dari jam'ah atau bahkan jarang dari jama'ah meninggalkan tempat duduknya hingga selesainya pembacaan hadis atau kultum yang dibawakan oleh mahasiswa STIBA Makassar

\section{DAFTAR PUSTAKA}

Adiyanto, Okka, and K K N Alternatif. "PENUMBUHAN KARAKTER ANAK USIA SEKOLAH BERBASIS MASJID MELALUI KULIAH KERJA NYATA ( KKN ) Menurut Data Informasi Kependudukan Provinsi Daerah Istimewa Yogyakarta Berjumlah Timur: Kelurahan Pakuncen: Kelurahan Notoprajan Selatan : Kelurahan Patangpuluhan.” Jurnal Pemberdayaan 2, no. 2 (2018): 333-40.

Aqbar, Khaerul, and Putra Alam. "Stimulasi Dakwah Menuju Masyarakat Qur'ani melalui KKN STIBA Makassar di Desa Alatengae Kabupaten Maros." WAHATUL MUJTAMA': Jurnal Pengabdian Masyarakat 1.2 (2020): 209221.

Usman, Mukran H. "Potret Dakwah dalam Kegiatan KKN STIBA Makassar di Desa Baruga Kabupaten Maros." WAHATUL MUJTAMA': Jurnal Pengabdian Masyarakat 1.1 (2020): 75-89.

Tempo, Rachmat Bin Badani, and Khaerul Aqbar. "Ikhtiar Mahasiswa KKN STIBA Makassar dalam Pembentukan Akhlak Qur'ani Masyarakat Desa Balassuka Kabupaten Gowa." WAHATUL MUJTAMA': Jurnal Pengabdian Masyarakat 1.1 (2020): 90-115.

Wulandari, Cheni Eka Putri, Sugiatno Sugiatno, and Siswanto Siswanto. "Dampak Kuliah Kerja Nyata Dalam Pengembangan Keagamaan Bagi Remaja." FOKUS Jurnal Kajian Keislaman Dan Kemasyarakatan 5, no. 2 (2020): 221. https://doi.org/10.29240/jf.v5i2.1830. 